\title{
Introspection of Characters in Fiction: Cultural Aspect
}

\author{
Oksana Fedotova \\ Department of Foreign Languages \\ Ryazan State University named for S. Yesenin \\ Ryazan, Russia \\ E-mail: ofedotova81@mail.ru
}

\begin{abstract}
The paper presents introspection as selfexamination by a fiction personage of his / her inner emotional, mental or physical state. With the help of introspection the reader can perceive the fictional world through the character's mind and senses, which helps to better decode the writer's message. Introspection should be distinguished from other categories used to describe the inner reality of a fiction character: character's flashbacks and flashforwards, presentation of the character's internal point of view, or the imitation of the character's stream of consciousness. Being part of virtual reality in fiction, introspection is a narrower notion, which embraces only the inner world of the character. The functions of introspection and the language markers that help to recognize introspection in the text are discussed. It is shown that apart from some obvious introspection markers like verbs, nouns and adjectives pertaining the semantic spheres of mental, intellectual and emotional manifestations, reference to the character's inner world makes the writer resort on a larger scale to figures of speech and conceptual metaphors. Introspection can be viewed as a text category in its own right as it performs functions of its own and has a peculiar set of cognitive and language means to represent it in the text.
\end{abstract}

Keywords-narratology; text category; introspection; inner reality of characters; fictional reality; virtual reality; functions of introspection; language markers; conceptual metaphor

\section{INTRODUCTION}

The study of different forms of reality in fiction is a comparatively recent development in narratology. Apart from fictional reality (dreams, flashforwards, etc.) there is another fruitful domain of research, namely the study of the inner reality of characters [1] [2] [3] [4] [5]. The inner world of a personage as part of the many-dimensional narrative reality structure needs further investigation as it has not been subjected to systematic study yet. The paper centers on introspection as self-examination by a fiction personage of his / her inner emotional, mental or physical state. With the help of introspection the reader can perceive the fictional world through the character's mind and senses, which helps to better decode the writer's cultural message. Introspection of a character is different from interior monologue and other forms of inner speech. To make our idea more explicit let us consider some examples.
- (1) He felt his smile slide away, melt, fold over, and down on itself like a tallow skin, like the stuff of a fantastic candle burning too long and now collapsing and now blown out. Darkness. He was not happy. He was not happy. He said the words to himself. He recognized this as the true state of affairs. He wore his happiness like a mask and the girl had run off across the lawn with the mask and there was no way of going to knock on her door and ask for it back [6].

In this example we get an insight into the inner world of a personage who is analyzing the change of his emotional state. Such figures of speech as metaphors (he felt his smile slide away, melt, fold over, and down on itself) and simile (like a tallow skin) reveal the change of disposition of the protagonist. The comparison of the character's inner state with the flame of a candle (like the stuff of a fantastic candle burning too long and now collapsing and now blown out) shows that fire is as changeable as the emotional state of the personage. However, the following words can hardly be referred to the examination of the character's thoughts and feelings as it is an obvious case of inner speech. Repetition (He was not happy) and the opposition of light and darkness add to the impression of despair, which is not made to be felt but is presented as the writer's conclusion. The next phrase "He recognized this as the true state of affairs" points at the character's awareness, which is part of his introspection, while the statement "He wore his happiness like a mask" might be interpreted in both ways. On the one hand, the character realizes that he presents a false show of emotions (introspection) but on the other hand, the writer might inform the readers about the character's face being like a mask of happiness. The concluding part of the context beginning with "and the girl..." cannot be treated as introspection because the hero is not reflecting over his emotional state any more. His consciousness floats to reminiscences where we see actions and descriptions of relationships.

In the second context the personage is going through a family drama. He is trying to solve the problem, to find the way out and he speculates on his feelings and emotions. The shift to the internal point of view like in the previous context is marked by figures of speech. The sufferings of the character are compared with those of a captain of a sinking ship who has to throw over "the most precious of his bales" 
to save the ship. Imagery seems to be especially helpful in marking off introspective passages. As is known, it is very difficult to define one's own emotional state, and resorting to an image one can get a better insight into what he / she feels:

- (2) A divorce! Thus close, the word was paralyzing, so utterly at variance with all the principles that had hitherto guided his life. Its lack of compromise appalled him; he felt like the captain of a ship, going to the side of his vessel, and with his own hands throwing over the most precious of his bales. This jettisoning of his property with his own hand seemed uncanny to Soames [7].

In context (3) it becomes obvious that the inner thoughts of the character and not his emotions might form the core of an introspective passage. Besides emotional and evaluative information this context gives factual information as well as contributes to the progress of narration. The reader learns the reasons for Leonardo's death and the analysis of the motives of Illuminati. The question the protagonist asks himself is inner speech, and as we have seen above, introspection, inner speech and narration may be intertwined in one context.

- (3)The comment hit home. Langdon suddenly found himself thinking of the antireligious Illuminati. Reluctantly, he forced himself to permit a momentary intellectual foray into the impossible. If the illuminati were indeed still active, would they have killed Leonardo to stop him from bringing his religious message to the masses? Langdon shook off the thought [8].

\section{THE STATUS OF INTROSPECTION IN A LITERARY TEXT}

The presence of the characters' introspection in modern fiction can hardly be denied but the status of introspection in a literary text is far less obvious. It might be referred to inner speech and related phenomena, but we think it plausible to treat characters' introspection as a text category in its own right. To prove it two aspects should be considered:

- Whether introspection as a text category possesses the content side distinguishing it from all other text categories;

- Whether introspection has a set of formal markers in the narrative.

Let us consider the former problem first.

Introspection should be distinguished from other categories used to describe the inner reality of a fiction character: character's flashbacks and flashforwards, presentation of the character's internal point of view, or the imitation of the character's stream of consciousness. Being part of virtual reality in fiction, introspection is a narrower notion, which embraces only the inner world of a character.

To distinguish introspection from the neighboring phenomena it is important to pay attention to the space in which the action takes place and to the way the inner state of a personage is shown. In other words, indication of the fictional (quasi-real) physical space as the stage of some events points at phenomena other than introspection. The evaluation of probability of events, speculation about their importance to the character, the realization by a character of his / her inner emotional, intellectual and physical state indicate that we deal with introspection.

The time element is less informative.

In case of the character's flashbacks and flashforwards the time of the narration changes. Such changes of time can also happen in introspection. To illustrate the difference let us study the following contexts:

- (4) She was jolted out of her reverie and floundering for an answer. She and Jack had discussed ways they might handle just such a question from Danny, ways that had varied from evasion to the plain truth with no varnish on it. But Danny had never asked [9].

- (5) She could not remember when she had last been so angry, so furious that her stomach had tied itself in a gripping, groaning knot [10].

In context (4) Wendy is trying to remember some events of the past and, to be more exact, their conversation with Jack when they discussed answers to their son's questions. In spite of the fact that we deal with the character's flashbacks all thoughts cover the level of events, and the readers do not get any information about Wendy's inner state. There is a change in space, but we do not gain access to the character's inner space. The readers just deal with events that took place in the past.

As far as context (5) is concerned, here the readers deal with the inner emotional and mental state of the character. Donna is analyzing her feelings and comes to an understanding that "she had never been so furious" in all her life. The reader leaves the real (fictional) physical space and floats deep into Donna's inner world, her inner self.

Thus, it is possible to conclude that not every flashback is necessarily introspective.

Correspondence between the character's flashforwards and introspection is still more difficult to determine because future is more subjective than the past. Even if we plan something there is always probability that everything will turn the other way round. In other words, we can never be absolutely sure about our future. That is why most of characters' flashforwards overlap with introspection. The characters' flashforwards seem to be free from introspection only when the plans we make are devoid of any emotional overtones, as for instance in context (6):

- (6) Three minutes from now, she thought, I'll be putting my key in my house door [11].

There is a close connection between the character's stream of consciousness and introspection because both phenomena are part of the inner world of a character and they are used to convey his / her feelings and emotions. But in case with introspection we deal with conscious and intentional analysis of the character's feelings and actions whereas the stream of consciousness contains all kinds of information and images which are simply indicative of 
brainwork, but not a kind of dialogue of a character with his / her inner self the aim of which is to understand the reasons for some events and actions, to analyze one's motives and feelings. So, the notion of the character's stream of consciousness seems to be much wider than introspection, though, by definition, the stream of consciousness includes introspection as its constituent part.

In its turn, the difference between the presentation of the character's point of view and his / her introspection is rather difficult to determine. However, in case with introspection the person himself / herself is the object of analysis while opinion may be rooted in anything whatever.

As we have seen, introspection and neighboring phenomena under discussion can correlate in one context:

- (7) As he stared up at Camerlengo Ventresca, Mortati felt the paralyzing collision of his heart and mind. The vision seemed real, tangible. And yet... how could it be? Everyone had seen the camerlengo get in the helicopter. They had all witnessed the ball of light in the sky. And now, somehow, the camerlengo stood high above them on the rooftop terrace. Transported by angels? Reincarnated by the hand of God?

It is impossible...

Mortati's heart wanted nothing more than to believe, but his mind cried out for reason. And yet all around him, the cardinals stared up, obviously seeing what he was seeing, paralyzed with wonder [12].

The first two sentences of context (7) represent introspection of the character who is trying to analyze the situation. His thoughts and feelings, reason and emotions are in collision (felt the paralyzing collision of his heart and mind). In the rest of the sentences of the first paragraph and in the phrase constituting the second paragraph it is possible to observe the protagonist's interior monologue. Different images float in his mind as some kind of flashbacks. The reader is following the thoughts of the character without concentrating, however, on his inner state, and only registering the chain of events. In the third paragraph of the context (7) the narration is presented from the point of view of one of the characters (Mortati). The first sentence contains introspection, i.e. concentration of the character on his inner state (Mortati's heart wanted nothing more than to believe, but his mind cried out for reason). In the last sentence the voice of the author overlaps with the voice of the personage and it is difficult to distinguish between the two. But still the phrase "paralyzed with wonder" may be treated as introspection, because only the character himself can feel paralyzed and determine the reason for it (wonder).

Another context is also suggestive of an overlap between introspection and inner speech in the narrative:

- (8) God, she's thin, I thought. She's nothing but a bag of -

A shudder twisted through me at that. It was a strong one, as if someone were spinning a wire in my flesh. I didn't want her to notice it - what a way to start a summer day, by revolting a guy so badly that he stood there shaking and grimacing in front of you - so I raised my hand and waved. I tried to smile, as well. Hello there, lady standing out by the floating bar. Hello there, you old bag of bones, you scared the living shit out of me but it doesn't take much these days and I forgive you... I wondered if my smile looked as much like a grimace to her as it felt to me [13].

The narration in context (8) is presented from the point of view of the protagonist. The context begins with the inner speech of the character which in the very next sentence gives way to introspection: only the protagonist can know about his inward shudder and feel excruciating sensation comparing it with the spinning wire in his flesh thus bringing out an image to convey information about the protagonist's inner emotional state. The inner monologue of the character which is addressed to Miss Whitmore follows interspersed with introspection (given in italics).

\section{FUNCTIONS OF INTROSPECTION}

Introspection plays an important role in fiction. Among major functions of introspection it is possible to distinguish: the function of portraying and evaluating a character which is further subdivided into the function of representation of mental activity, of inner emotional state and motivation to the character's actions and the function of registering the protagonist's impressions which includes attitude to the people around, attitude to the world and events of virtual reality.

To support our finding with the language material we shall discuss the above-mentioned functions in more detail giving narrative contexts to illustrate the above-enumerated functions.

\section{A. The Function of Representation of Mental Activity}

- (9) He had been dumping a change of clothes into an overnight bag when the thought came to him, freezing him with the power of the memory as it always did when he thought of it. He tried to think of it as seldom as possible [14].

- (10) The object was covered with a grey plastic hood. I reached out to touch it, and my hand faltered an inch or two short as a memory of an old dream slipped across my mind much as that queer draft had slipped across my face. Then it was gone, and I pulled the plastic cover off. Underneath it was my old green IBM Selectric, which I hadn't seen or thought of in years [15].

\section{B. The Function of Conveying Information About the Inner Emotional State of the Protagonist}

- (11) She stopped, she froze, she clung to the wooden banister. Her heart exploded in her. The sound of the terrified beating filled the universe [16]. 
C. The Function of Providing Motivation to the Character's Actions

- (12) June was abandoned, and for the sake of that fellow's son! He felt it was true and hardened himself to treat it as if it were not; but the pain he hid beneath his resolution began slowly, surely to vent itself in a blind resentment against James and his son [17].

D. The Function of Discovering the Protagonist's Attitude to the People Around

- (13) He saw himself in her eyes, suspended in two shining drops of bright water, himself dark and tiny, in fine detail, the lines about his mouth, everything there, as if her eyes were two miraculous bits of violet amber that might capture and hold him intact. Her face, turned to him now, was fragile milk crystal with a soft and constant light in it [18].

\section{E. Through Introspection We Can See the Attitude of the} Protagonist to the World and Events of Virtual Reality

- (14) She looked out the window and saw that the sun was getting ready to go down. A superstitious dread settled into her at the thought. She remembered the childhood games of hide-and-seek that had always ended when the shadows joined each other and grew into purple lagoons, that mystic call drifting through the suburban streets of her childhood, talismanic and distant, the high voice of a child announcing suppers that were ready, doors ready to be shut against the night... [19]

- (15) And looking at one single label on a jar, he felt himself gone round the calendar to that private day this summer when he had looked at the circling world and found himself at its center [20].

\section{MARKERS OF INTROSPECTION}

Going over to the point of the markers of introspection in the narrative it is possible to state that introspection is seldom introduced by verbs denoting mental activity as they are usually used to introduce the protagonist's thought. However, verbs denoting realization and awareness (to realize, to believe, to be aware, to wonder, etc.) are more common in marking off introspective passages:

- (16) Jennifer could not believe the sudden horrifying publicity that was being showered on her. They were hammering at her from all sides: television reporters, radio reporters and newspaper people. She wanted desperately to flee from them, but her pride would not let her [21].

- (17) When she looked at him now she wondered what there was in him that had ever aroused in her such a frenzy of passion [22].

- Besides, there are some obvious introspection markers like verbs, nouns and adjectives pertaining the semantic spheres of intellectual and emotional manifestations:
- (18) Danny, as always, felt a warm burst of pleasure at seeing his old friend, but this time he seemed to feel a prick of fear, too, as if Tony had come with some darkness hidden behind his back [23].

- (19) The smouldering jealousy and suspicion of months blazed up within him. He would put an end to that sort of thing once and for all; he would not have her drag his name in the dirt! [24]

- (20) He could hear the sound of his own heart [25].

- (21) For several seconds, although Sexton was still talking, all Gabrielle could hear was the blood rushing in shame to her face [26].

As it was mentioned above, reference to the character's inner world makes the writer resort on a larger scale to figures of speech and, in general, to imagery. Here we can cite one more example where simile is used to bring out the intensity of the protagonist's emotions:

- (22) Rachel felt a distant pang of loneliness. Like the howling wind outside the plane, the memories came tearing back, pulling at her the way they always did. Their final conversation had been by phone. Thanksgiving morning [27].

The study of the introspective passages in the literary text in the English language revealed one more tendency of interest which points at the role of conceptual metaphor in marking off the characters' introspection.

Conceptual metaphor is understanding and experiencing of one kind of thing in terms of another. The linguists state that metaphor is pervasive in everyday life, not just in language but in thought and action as well. Human thought processes are largely metaphorical and human conceptual system which is metaphorically structured and defined [28] [29]. As an example in their work Metaphors we live by, G. Lakoff \& M. Johnson (1980) analyze the metaphorical concept TIME IS MONEY (You are wasting my time; This gadget will save you hours; etc.) which is especially important in Western culture where work and other things are associated with the time it takes. Thus, time is understood as the kind of thing that can be "spent, wasted, budgeted, invested wisely or poorly, saved or squandered".

The language material studied showed that there are some conceptual metaphors that are repeatedly used as pointers to the characters' introspection. For example, let us consider the conceptual metaphor of CONTAINER. Here a person is viewed as a container and his emotions are substances that fill the container:

- (23) Horror crept softly into his veins and into his brain as he began to walk toward the short hall [30].

- (24)... a dreamy terror floated into the dark hollows of his body like light brown spores that would die in sunlight [31]. (see also contexts (19) (20) (21)).

We can point at a group of metaphorical concepts that are quite common in representing the inner emotional 
and mental state of a character. This group includes, in part, the representation of the INNER EMOTIONAL STATE OF A CHARACTER AS OVERCROWDED SPACE:

- (25) He didn't dare say more. His head was throbbing with the hot, acid-etched words that wanted to get out [32].

- (26) And then a thundering wave of misery seemed to course through her veins [33].

The inner state of a character may be represented as an ENCLOSED SPACE:

- (27) Across the room, Vittoria was immersed in her own search. Standing all alone for the first time since she had heard the news of her father, she felt the stark reality of the last eight hours closing in around her [34].

The inner reality of a character may be metaphorically represented as UNREAL, VIRTUAL SPACE or a JOURNEY:

- (28) Now, in the dim, shifting light of the train, Gabrielle felt like she was enduring some kind of hallucinogenic drug trip. Muted lights whipped by overhead like slow motion discotheque strobes. The ponderous tunnel rose on all sides like a deepening canyon [35].

- (29) Celia died on a crystal-clear Sunday morning in June. Michael Tolland felt like a ship torn from its moorings and thrown adrift in a raging sea, his compass smashed. For weeks he spun out of control. Friends tried to help, but his pride could not bear their pity [36].

The THEATRE metaphor is also among the prominent ones:

- (30) Standing there atop the magnificent stairs that spilled down the piazza below, Langdon felt like a reluctant player on the world's biggest stage. Somewhere beyond the glaring lights, Langdon heard an idling helicopter and the roar of a hundred thousand voices [37].

It is noteworthy that a group of conceptual metaphors based on natural phenomena is quite frequent.

Reference to the protagonist's emotional or intellectual state may be metaphorically made through the indication of changes in temperature:

- (31) Danny, as always, felt a warm burst of pleasure at seeing his old friend [38].

Or as fire:

- (32) And the slow sulk anger Soames had felt all the afternoon burned the brighter within him [39].

- (33) Her silver-mounted brushes smelt faintly of the perfumed lotion she used for her hair; and at this scent the burning sickness of his jealousy seized him again [40].

The case of fire and high temperature in representing emotional states has already been amply discussed in [41], but water, fog, as well as the opposition of light and darkness can be viewed as pointers at the character's introspection.

- WATER: (34) Jack sat looking down at him (Danny) for a moment, and a rush of love pushed through him like tidal water [42].

- FOG: (35) Onboard the Goya, Rachel felt lightheaded The mystification that had settled around her like a heavy fog was lifting now. The stark reality that came into focus left her feeling naked and disgusted [43].

- (36) Now, however, that such a thing or rather a rumour, the breath of it - had come near him personally, he felt as in a fog, which filled his mouth full of a bad, thick flavour, and made it difficult to draw breath [44].

\section{CONCLUSION}

To sum up, introspection can be viewed as a text category in its own right as it performs functions of its own and has a peculiar set of cognitive and language means to represent it in the text. Furthermore, introspection allows a reader to comprehend a fictional world through characters' eyes thus getting a more profound understanding of their personality and their relationships with other characters. This, in its turn, causes a deeper understanding of the message of the writer.

\section{REFERENCES}

[1] M. Jahn, 'Awake! Open your eyes!' The cognitive Logic of External and Internal Stories // Narrative Theory and Cognitive Sciences. Edited by David Herman. CSLI Stanford, California, 2003. pp. 195 214.

[2] U. Margolin, Cognitive Science, the Thinking Mind, and Literary Narrative // Narrative Theory and Cognitive Sciences. Edited by David Herman. CSLI Stanford, California, 2003. pp. 271- 295

[3] Palmer, Fictional Minds. Lincoln: University of Nebraska Press, 2004

[4] M.-L. Ryan, Cognitive Maps and the Construction of Narrative Space // Narrative Theory and Cognitive Sciences. Edited by David Herman. CSLI Stanford, California, 2003. pp. $214-243$.

[5] M. Turner, Double-scope stories // Narrative Theory and Cognitive Sciences. Edited by David Herman. CSLI Stanford, California, 2003. pp. $117-143$.

[6] R. Bradbury, Fahrenheit 451. Saint-Petersburg: Anthology, 2004, p. 9

[7] J. Galsworthy, The Man of Property. Moscow: Manager Edition, 2000, p.299.

[8] D. Brown, Angels and Demons. London: Corgi Edition, 2001, p. 65.

[9] S. King, The Shining. New York: A Signet Book, 1978, p. 13.

[10] S. King, Cujo. New York: A Signet Book, 1982, p. 39.

[11] R. Bradbury, Dandelion Wine. Moscow: Iris Press, 2005, p. 201.

[12] D. Brown, Angels and Demons. London: Corgi Edition, 2001, p. 558.

[13] S. King, Bag of Bones. New York: Scribner Books, 1998, p. 122.

[14] S. King, The Shining. New York: A Signet Book, 1978, p. 317.

[15] S. King, Bag of Bones. New York: Scribner Books, 1998, p. 129. 
[16] R. Bradbury. Dandelion Wine, p. 202.

[17] J. Galsworthy, The Man of Property. Moscow: Manager Edition, 2000, p. 186.

[18] R. Bradbury. Fahrenheit 451, p. 6.

[19] S. King. Cujo, p.162.

[20] R. Bradbury, Dandelion Wine, p. 263.

[21] S. Sheldon, Rage of Angels. New York: Warner Books Edition, 1983, p. 32.

[22] W.S. Maugham, Theatre. Moscow: Manager Edition, 2002, p. 74.

[23] S. King, The Shining. New York: A Signet Book, 1978, p. 31.

[24] J. Galsworthy, The Man of Property. Moscow: Manager Edition, 2000, p. 299.

[25] D. Brown, Digital Fortress. London: Corgi Edition, 2004, p. 424.

[26] D. Brown, Deception Point. London: Corgi Edition, 2004, p. 354.

[27] Ibid., p. 83.

[28] G. Lakoff, M. Johnson. Metaphors we live by. Chicago: University of Chicago Press, 1980.

[29] G. Lakoff, M. Turner, More than Cool Reason: A Field Guide to Poetic Metaphor. Chicago: University of Chicago Press, 1989.

[30] S. King, The Shining. New York: A Signet Book, 1978, p. 416.

[31] Ibid., p. 32.

[32] Ibid., p. 188.

[33] D. Brown, Digital Fortress. London: Corgi Edition, 2004, p. 179.

[34] D. Brown, Angels and Demons, p. 277.

[35] D. Brown. Deception Point, p. 235.

[36] Ibid., p. 178.

[37] D. Brown, Angels and Demons, p. 517.

[38] S. King, The Shining. New York: A Signet Book, 1978, p. 31.

[39] J. Galsworthy, The Man of Property. Moscow: Manager Edition, 2000, p. 120.

[40] Ibid., p. 301.

[41] G. Lakoff, M. Johnson, Metaphors we live by. Chicago: University of Chicago Press, 1980.

[42] S. King, The Shining. New York: A Signet Book, 1978, p. 129.

[43] D. Brown, Deception Point. London: Corgi Edition, 2004, p. 520.

[44] J. Galsworthy, The Man of Property. Moscow: Manager Edition, 2000 , p. 145. 